\title{
Georgian Electoral System - Current Problems and Challenges
}

\author{
Sophio Demetrashvili* \\ Mariam Jikia**
}

ARTICLE INFO

Article history:

Accepted: October 302020.

Approved: December 152020.

\section{Keywords:}

Elections, Proportional Electoral System, Georgian Electoral System.

\section{A B S T R A C T}

According to the definition of modern democracy, the main means of control of the government by citizens is free elections. Elections are a necessary condition for the democratic nature of the state and not a guarantee of it. The election is the key factor in the functioning of democratic systems, which determines the relevance of this topic.

The article concerns the Georgian Electoral System, its characteristics, and existing problems; in detail reviews the establishment of the electoral system and the existing regulations of electoral procedures.

The article reviews the current problems related to the amendment of the Constitution that includes the transformation of the electoral system to a totally proportional electoral system. The authors gave a detailed analysis of the given draft law and comparative analysis regarding the German electoral system.

With respect to democratic principles, thus, any electoral system may be chosen, regardless if it is a plurality or majority system, a proportional system, or a combined system. It should be underlined that there is no such thing as the "best" electoral system that could be exported to all countries in the world. Thus, the electoral system and proposals to reform should be assessed in each individual case.

(C) 2020 Published by the Institute for Development Studies, Sulkhan-Saba Orbeliani University.

\section{Introduction}

The historical development of society has caused the formation of a new political regime such as democracy, which represents the government of the people, exercised by the people and for the people. Elections, political rights, and the involvement of citizens are key components of democracy. However, elections are not only an important component of democracy but the cornerstone and prerequisite of it (Center for Electoral Systems Development, Reforms and Trainings, 2014-2015).

The granting of basic human rights and freedoms is the result of democratic transformations. The democratic principle of equality

* Doctor of Law, Georgian Technical University, Tbilisi, Georgia.

** Doctor of Law, Georgian Technical University, Tbilisi, Georgia. 


\section{JOURNAL OF DEVELOPMENT STUDIES}

means equality before the law, equal suffrage, as well as equal access to public authority and Office (Государственное право Германии, 2002).

In the modern sense, elections are a major form of realization of national sovereignty, the formation of state bodies through universal suffrage. According to Article 3, Paragraph 1 of the Constitution of Georgia, "Georgia is a Democratic Republic". The Constitution of Georgia reinforces an important aspect of democracy - the principle of national sovereignty (Degenhart \& Staatsrecht, 2002), according to which "the source of state power is the people" (The Legal Education and Justice Centre). Due to Article 3 (2) of the Constitution, "the people exercise their power through their representatives, as well as through referendums and other forms of direct democracy." Democracy is, first and foremost, the realization of public sovereignty, where the participation of the people is the basic essence and purpose of democracy (The Citizen of Georgia Giorgi Ugulava vs Parliament of Georgia, 2014, II, paragraph 9). Therefore, the idea of public sovereignty serves to ensure that people's participation in the process of government and, as a result, the realization of direct democracy, must be achieved at all levels (The Citizen of Georgia Giorgi Ugulava vs Parliament of Georgia, 2014 II, paragraph 10).

\section{Georgian electoral system}

The quality of democratic elections and the relevant universal and equal suffrage depend on a variety of factors, including the high-political and legal awareness and highly qualified election administration.

${ }^{1}$ The first elections were based on the "Election Regulations of the Constituent Assembly" adopted by the Parliament of the Republic of Georgia on
Georgia's electoral system was established in $1919^{1}$. In general, election law regulates the process of elections of public authorities and officials and establishes the electoral procedure. Since electoral law is an integral part of constitutional law, among the legal acts regulating elections in Georgia, the constitution of Georgia guarantees civil and political rights that are essential for democratic elections (Center for Electoral Systems Development, Reforms and Trainings, 5, 2014-2015). Due to Article 9, paragraph 9 on Changes to the Constitutional Law of Georgia of 23 March 2018, "the Parliament elected in the next Parliamentary elections shall consist of 77 members elected by a proportional system by universal suffrage for a term of four years and 73 parliamentarians elected by the majoritarian system on the basis of universal, free, equal and direct suffrage. As a result of proportional system elections, the mandates of MPs will be distributed to the political parties and election blocs of political parties that receive at least $3 \%$ of the votes. The rules and conditions for participation in elections, as well as the rules for the distribution of seats for MPs, shall be determined by election law." A majoritarian constituency shall be deemed to be the candidate for membership of the Parliament of Georgia, having received more than half of the votes. Elections of the representative body of local self-government -are held on the basis of proportional and majoritarian electoral systems. The candidate who received more than $50 \%$ of the votes in the election of Mayor shall be considered elected.

According to Article 50 (1) of the Constitution of Georgia, "The President of Georgia shall be elected by open ballot without debate for a term of five years. The same person can be elected as the President of Georgia

November 22, 1918, which envisaged the election of 130 members through a proportional electoral system based on universal suffrage. 


\section{JOURNAL OF DEVELOPMENT STUDIES}

only twice." According to Section 3 of the same article, "The Electoral Board shall comprise 300 members, including all members of the Parliament and the highest representative bodies of the Autonomous Republics of Abkhazia and Adjara. Other members of the Electoral Board shall be nominated by the relevant political parties per the quotas established by the Central Election Commission of Georgia, in accordance with the quotas defined by the Central Election Commission of Georgia based on law. Quotas are determined by observing the principle of geographic representation and proportional to the results of local self-government elections. The composition of the Electoral Board shall be approved by the Central Election Commission of Georgia."

Electoral law is based on five basic principles: universal suffrage, equal suffrage, direct suffrage, secret ballot, free elections. However, there are restrictions that determine the circle of persons entitled to vote: citizenship, residence ${ }^{2}$ age $^{3}$, education, etc.

Preparing, conducting, and summarizing the results of Elections are provided by the Election Administration of Georgia, the independent body from governing authority. Mentioned institution consists of the Central Election Commission of Georgia (CEC), the Supreme Election Commission of the Autonomous Republic of Adjara (SEC), DECs, and PECs (Center for Electoral Systems Development, Reforms and Trainings, 16, 20142015).

The rules of operation of the Election Administration of Georgia are defined by the election Code of Georgia and the Election Administration Regulations (Center for Electoral

\footnotetext{
2 Minimum time of residence in the state or its administrative unit after which the person obtains the right to vote. The Georgian legislation does not explicitly specify a residence permit for active suffrage; however, the unified voter list shall
}

Systems Development, Reforms and Trainings, 23, 2014-2015).

Voter registration is of significant importance for the electoral process. Depending on who bears the burden of registration of voters, registration can be public (mandatory) or personal (voluntary). During public or compulsory registration, the authorities are obliged to identify all voters and enter them into a unified voters' list. On the other hand, voluntary or personal registration implies voter-initiated registration (Center for Electoral Systems Development, Reforms and Trainings, 30, 2014-2015).

In general, the establishment of a wellfunctioning political system is an important condition for establishing and consolidating a well-functioning representative democracy (Kakachia \& Pataraia, 2013). Although the Georgian government is seeking to consolidate democratic gains, it's clear that today's society lacks the strong political will and experience of democratic governance.

One of the main preconditions for consolidating democratic institutions is to strengthen political parties, especially to maintain a multi-party system. Political parties are presumed to be central to the democratization of any state (Makara, 2009). More recent scientists on political parties believe that parties are inevitable for a democracy to work (Huntington, 1968).

\section{Current Issue concerning parliamentary elections of Georgia}

Draft of Constitutional amendments, voted on November 14, 2019, in the Parliament of Georgia, proposed to introduce a proportional electoral system and a natural

contain the data of the voter according to the place of his/her registration.

${ }^{3}$ specific age at which a citizen acquires the right to vote. Citizens of Georgia acquire active voting rights from the age of 18 . 


\section{JOURNAL OF DEVELOPMENT STUDIES}

barrier in the next parliamentary elections with three-quarters of votes ${ }^{4}$, was adopted by a two-thirds majority ${ }^{5}$. It means that the first hearing failed. There is an opinion that the second and third hearings of the draft law should be held.

However, neither the Constitution of Georgia nor the Election Code provides for detailed regulation of mentioned. However, the proposed draft, which offers the proportional system for the next parliamentary elections, excludes the approval of the amendment by the first procedure, since its approval by the next parliament loses the sense, cause it's the election of the next parliament itself.

Both the reality in the country and the initiative proposed by the Venice Commission suggest that it's desirable to have a twochamber parliament, where the lower chamber to be elected by a proportional system, and the upper chamber - by a majoritarian system. The majoritarian system is not vicious and should not be abolished, but it's advisable to think about its relevant use.

In general, the majoritarian system is widespread throughout the world. The majoritarian system is exercised by the US Congress, Bundestag, House of Commons in the UK, etc. That is, in terms of distribution, a majoritarian system has the right to exist, as well as a proportional system. The main purpose of the majoritarian system is to represent the interests of the territorial units in the country's highest representative body.

\section{German electoral model}

After the proposed amendment failed the idea of introducing the so-called "German model" has emerged in the public.

German electoral model is characterized by a mixed electoral system, as majoritarian candidates still run in the elections, however, the parties will only enter the parliament with the same number of MPs as they would get through the proportional electoral system. The main principle of this model is that a fixed number of parliamentarians will not be replaced, as the sum of the MPs withdrawn from one party, both on the majoritarian and proportional basis, must depend on the outcome of the party's proportional election. In fact, the German electoral model implies that "if the candidates nominated by one or more electoral actors have received as many or more seats in the majoritarian elections as the political party in accordance with paragraphs 6 to 8 of this article, the number of mandates assigned to other parties is calculated by the following formula:

$$
N k=M k \times(150-P-P 1): M 1
$$

$N k$ is the number of seats belonging to $k$ (who won less than the mandate specified in paragraphs 6 to 8 of this article in the majoritarian elections);

$M k$ is the number of votes received;

$P$ - under the majoritarian system number of MPs elected by the political parties, who failed to overcome the electoral threshold; $P 1$ - the number of Members of Parliament elected by the political actors having obtained as many or more seats in the majoritarian elections as they had in accordance with paragraphs 6 to 8 of this article;

M1 - is the sum of the votes received by those political actors who received less mandate in the majoritarian elections than they had in accordance with paragraphs 6 to 8 of this article.

If the sum of all $N k$ is found to be less than (150 -P-P1) the mandates per unallocated mandate is additionally given to those entities that have more balances when calculating the above Nk. Thereafter, the number of

${ }^{5} 101$ Votes.

${ }^{4} 113$ Votes. 


\section{JOURNAL OF DEVELOPMENT STUDIES}

seats in the party list of Nk actors shall be determined in accordance with the procedure laid down in paragraph 9 of this article.

The German electoral system is completely different. The form of government is not straightforward but representative, with elected deputies playing a central role. Legislative decisions are made only by lawmakers elected by the people. Consequently, a significant part of the responsibility falls on MPs. Moreover, the constitution of the Federal Republic of Germany emphasizes the role of Bundestag, MPs representing the people. In addition, the German constitution also imposes the function of controlling ordinary voters.

As we have noted, the German electoral model is characterized by a mixed system, with some MPs running in the single-mandate constituency and some according to the party list. The Bundestag adheres to the principle of proportion. Half of the composition of the Parliament is personally voted by the voters. According to Article 38, Part 1 of the Constitution of the Federal Republic of Germany, every adult (18 years and older) citizen has the right of giving 2 votes (Grundgesetz für die Bundesrepublik Deutschland, A. 38). Voters vote first for a specific candidate, and second - for a particular party. In this, the priority shall be given to the second one, which determines the political situation in the country, the ratio of forces in the Bundestag, and also which party will be the chancellor who is usually elected by the Bundestag. By the second vote that the issue of majority and minority in the Bundestag is resolved by the voters. When it is known how many seats each party has received by the number of second ballots, then the parliamentary seats are divided according to the party list. The second vote comes from the party that overcame at least a $5 \%$ threshold in the German legislature. The number of seats won by any party in the Bundestag is directly proportional to the number of second ballot cast. Those seats are being filled by those party candidates who won single-mandate constituencies. If their number is less than the number of seats received, then the seats are divided by party list. If the opposite happens and the number of single-mandate constituencies is higher than the seats won by the party, an additional mandate will be created for such candidates. Nowadays, there is a substantial debate in Germany on eliminating the shortcomings of this system, as the total number of MPs is increasing as a result of the Bundestag election system.

\section{Conclusion}

The electoral system has to reflect the will of the people. The conversion of votes to political mandates depends largely upon the electoral system (Venice Commission, 2019). With respect to democratic principles, thus, any electoral system may be chosen, regardless if it is a plurality or majority system, a proportional system, or a combined system. It should be underlined that there is no such thing as the "best" electoral system that could be exported to all countries in the world (Venice Commission, 2019). Thus, the electoral system and proposals to reform should be assessed in each individual case.

It's clear that the electoral system is completely incompatible with the Constitution of Georgia and the current practical situation, but it is important to come up with a correct wording to understand what the current opposition parties have to offer. Constitutional Law of Georgia of October 13, 2018, on "Amending the Constitution of Georgia", "Amending the Constitutional Law of Georgia", in accordance with Article 9, Paragraph 9, "The Parliament elected in the next Parliamentary Elections shall consist of 77 members elected by a proportional system for a term of 4 years and 73 deputies elected by the majoritarian system by universal and equal suffrage, direct and free elections. As a 


\section{JOURNAL OF DEVELOPMENT STUDIES}

result of the proportional system, the mandates of the MPs will be distributed to the political parties and election blocs of political parties that receive at least $3 \%$ of the votes cast. The rules and conditions for running in elections, as well as the rules for the distribution of seats for Members of Parliament, shall be determined by election law." This provision makes it clear that the Parliament of Georgia will be composed of 77 MPs elected through a proportional system and 73 MPs elected by the majoritarian system, the terms, and conditions of the elections, as well as the procedure for distribution of seats, are regulated by the electoral legislation of Georgia. However, according to the proposed project, if the political party receives $10 \%$ of the total votes and 15 seats out of 150 seats are proportionally received, these mandates are owned, for example, by 6 winning majoritarians and 9 candidates from the party list. As a result, the winning majoritarians unconditionally receive mandates, and as many MPs are added to the party list as needed to fill the mandates up to the total number of seats in the party. Accordingly, both the proportionality requirement and the requirement for the maintenance of majoritarian constituencies are met simultaneously. It is also noteworthy that this initiative in practice requires only 76 votes.

In conclusion, it is a mistake when the opposition offers to adopt a "German model" because the initiative they propose is not a German model, but rather a modified variation of it. In the proportional system, the mandates are distributed proportionally to the number of votes received, and the majoritarian system includes the majority distribution of votes. According to the "German Model", deputies' proportional representation depends on the party's mandates in parliament by majoritarian rule. The constitution

\footnotetext{
${ }^{6}$ For example, Mexico, where the revolutionarydemocratic party has been in power for 30 years.
}

of Georgia does not define the beginning of the proportionality. As a result, the parliament is still composed of 73 majoritarian MPs and 77 MPs elected by proportional list. In fact, the main problem lies in the "will of the authorities". It should also be noted that the best way to solve the problem is a two-chamber parliament, which was repeatedly recommended by the Venice Commission.

There are some very interesting developments in Georgia today, especially for lawyers. The main challenge remains the creation of a strong democracy and justice, which can be achieved through free choice and fair state policy (Mgaloblishvili, Fair Elections). Fair elections are an essential part of the democratic development process. States with a multi-party electoral system are closer to the ideals of democracy and others, with characteristics of authoritarianism, aspiring to a dominant party system and are often characterized by non-democratic rule ${ }^{6}$. The existence of successful parties and a stable electoral environment are some of the fundamental requirements for States' further democratization.

\section{References}

Center for Electoral Systems Development, Reforms, and Training, Assistance Handbook for Students of Georgian Higher Education Institutions, 2014-2015, http://www.electionreforms.ge/res/docs/827.pdf [17.11.2019].

Degenhart, Ch., Staatsrecht, I. (2002). Staatsorganisationsrecht, Heidelberg, 23.

Grundgesetz für die Bundesrepublik Deutschland, Artikel 38, Absatz 1.

Huntington, S. P. (1968). Political Order in Changing Societies, 49.

Kakachia, K., Pataraia, T. (2013). The Role of Social Media in Georgian Party Politics, 17, Tbilisi.

Makara, S. (2009). the Challenge of Building Stron Political Parties for Democratic Governance in 


\section{JOURNAL OF DEVELOPMENT STUDIES}

Uganda: Does multiparty politics have a future? The East African Reviews, N41, 2009,

43-80 https://journals.openedi-

tion.org/eastafrica/580 [04.12.2019].

Mgaloblishvili, N. Fair Elections in the process of democratic development http://participate.ge/index.php?lang_id=GEO\&sec_id=43\&info_id=1 909 [02.12.2019].

The Citizen of Georgia Giorgi Ugulava vs Parliament of Georgia, №3/1/574, May 23, 2014.

The Legal Education and Justice Centre, https://jelec.iliauni.edu.ge/me-5-mukhlispirveli-punqti/ [12.11.2019].

Venice Commission (2019), European Commission for Democracy through Law (Venice Commission), Compilation of Venice Commission Opinions and Reports Concerning Electoral Systems, Strasbourg, 18 March 2019, 7.

Государственное право Германии, под редакции И. Изензее, К. Кирхоф, Хайдельберг, 1987-1992, 161-165. 